\title{
Role of Probiotics in Modulating Human Gut Microbiota Populations and Activities in Patients with Colorectal Cancer-A Systematic Review of Clinical Trials
}

\author{
Adrianna Wierzbicka ${ }^{1,+}$, Dorota Mańkowska-Wierzbicka ${ }^{2,+} \mathbb{D}$, Marcin Mardas ${ }^{3}$ and Marta Stelmach-Mardas ${ }^{1, * \mathbb{D}}$ \\ 1 Department of Obesity Treatment, Metabolic Disorders and Clinical Dietetics Poznań University of \\ Medical Sciences, Szamarzewskiego 84, 60-569 Poznań, Poland; duniakaw@gmail.com \\ 2 Department of Gastroenterology, Metabolic Diseases, Internal Medicine and Dietetics, Poznan University of \\ Medical Sciences, 84, 60-569 Poznań, Poland; dmankowska.wierzbicka@gmail.com \\ 3 Department of Oncology, Poznan University of Medical Sciences, 84, 60-569 Poznań, Poland; \\ marcin.mardas@ump.edu.pl \\ * Correspondence: stelmach@ump.edu.pl; Tel.: +48-697424245 \\ + These authors contributed equally to the work.
}

check for updates

Citation: Wierzbicka, A.; MańkowskaWierzbicka, D.; Mardas, M.; StelmachMardas, M. Role of Probiotics in Modulating Human Gut Microbiota Populations and Activities in Patients with Colorectal Cancer-A Systematic Review of Clinical Trials. Nutrients 2021, 13, 1160. https://doi.org/ $10.3390 /$ nu13041160

Academic Editor: Michael Conlon

Received: 19 February 2021

Accepted: 29 March 2021

Published: 1 April 2021

Publisher's Note: MDPI stays neutral with regard to jurisdictional claims in published maps and institutional affiliations.

Copyright: (c) 2021 by the authors. Licensee MDPI, Basel, Switzerland. This article is an open access article distributed under the terms and conditions of the Creative Commons Attribution (CC BY) license (https:/ / creativecommons.org/licenses/by/ $4.0 /)$.

\begin{abstract}
Background: Growing attention has been given to the role of nutrition and alterations of microbial diversity of the gut microbiota in colorectal cancer (CRC) pathogenesis. It has been suggested that probiotics and synbiotics modulate enteric microbiota and therefore may be used as an intervention to reduce the risk of CRC. The aim of this study was to evaluate the influence of probiotics/synbiotics administration on gut microbiota in patients with CRC. Methods: PubMed, Scopus, and Web of Science were searched between December 2020 and January 2021. Randomized controlled trials (RCTs) recruiting adults with CRC, who have taken probiotics/synbiotics for at least 6 days were included. Changes in gut microbiota and selected biochemical and inflammatory parameters (i.e., hsCRP, IL-2, hemoglobin) were retrieved. Results: The search resulted in 198 original research articles and a final 6 were selected as being eligible, including 457 subjects. The median age of patients was 65.4 years old and they were characterized by the median BMI value: $23.8 \mathrm{~kg} / \mathrm{m}^{2}$. The literature search revealed that probiotic/synbiotic administration improved enteric microbiota by increasing the abundance of beneficial bacteria such as Lactobacillus, Eubacterium, Peptostreptococcus, Bacillus and Bifidobacterium, and decreased the abundance of potentially harmful bacteria such as Fusobacterium, Porhyromonas, Pseudomonas and Enterococcus. Additionally, probiotic/synbiotic intervention improved release of antimicrobials, intestinal permeability, tight junction function in CRC patients. Conclusions: The use of probiotics/synbiotics positively modulates enteric microbiota, improves postoperative outcomes, gut barrier function and reduces inflammatory parameters in patients suffering from CRC.
\end{abstract}

Keywords: probiotics; gut microbiota; human microbiome; colorectal cancer; chronic diseases; micronutrients; supplementation; disease prevention

\section{Introduction}

In 2020, an estimated 147,950 new cases and an estimated 53,200 deaths will be attributed to Colorectal cancer (CRC) [1]. Given the multifactorial etiology, CRC is associated with nutrition, inflammatory processes, and genetic factors [2-4]. Based on the evidence, the consumption of processed meat, alcoholic beverages, and the accumulation of body fat significantly increases the risk of the development of the disease [4,5], whereas the consumption of fiber, calcium, milk, whole grains, vegetables and fruit reduces the risk of CRC [6]. Recently, growing attention has been given to the role of gut microbiota (i.e., Fusobacterium nucleatum, Escherichia coli, Enterococcus faecalis, Streptococcus gallolyticus, Bacteroides fragilis) in colorectal carcinogenesis [7]. The microbial diversity of enteric bacteria 
occurs in the cancer tissues which are directly exposed to microbes, such as the colon and rectum. Dysbiosis can be defined as an increase in proinflammatory species and a decrease in microbial diversity. Thus, any microbial imbalance may produce carcinogenic and genotoxic metabolites as well as trigger inflammatory process [8]. It has been shown that the supplementation of probiotics might be required to re-establish the homeostasis and to restore the environment $[9,10]$. Furthermore, probiotics benefit a host through several physiological functions such as protecting against pathogens, regulating host immunity, and strengthening the gut integrity [11-13]. In the context of CRC patients, the administration of probiotics may protect them from treatment-associated side effects [14,15]. Currently, probiotic supplementation has been proven to be a promising innovative approach to counteracting CRC progression [16]. In particular, some bacteria, mainly of the genera Lactobacillus and Bifidobacterium, have a potentially beneficial role in modulating the antiinflammatory response and protecting against enteric pathogens $[17,18]$. To date, their impact on gut homeostasis has been widely investigated.

Therefore, the aim of the study was to evaluate the influence of probiotics/synbiot-ics administration on gut microbiota changes in patients with CRC.

\section{Materials and Methods}

\subsection{Search Strategy and Study Selection}

The study was performed according to guidelines of the Preferred Reporting Items for Systematic Reviews and Meta-Analysis (PRISMA) [19].

A comprehensive search was conducted using the electronic databases: PubMed, Scopus, and Web of Science between December 2020 and January 2021 to identify randomized, controlled trials (RCT), clinical trials (CT), double-blind placebo trials (DBPT) run in adults (age over 18) diagnosed with either colorectal or colon or rectal cancer where an intervention with probiotics/symbiotic was analyzed in the context of gut microbiota changes. Studies recruiting adults with CRC who have taken probiotics/synbiotics for at least 6 days were included. Briefly, probiotics were defined according to the Food and Agricultural Organization of the United Nations and the World Health Organization as: "live microorganisms, which, when consumed in adequate amounts, confer a health benefit on the host" [20] and synbiotics as "mixtures of probiotics and prebiotics that beneficially affect the host by improving the survival and implantation of live microbial dietary supplements in the gastrointestinal tract of the host" [21].

Search terms included: ("Colorectal cancer" OR "Colonic Neoplasms" OR "Adenomatous Polyposis Coli" OR "Colorectal Neoplasms, Hereditary Nonpolyposis" OR "Rectal Neoplasms" OR "Colorectal Carcinoma" OR "Sigmoid neoplasms" OR "Anus Neoplasms" OR "Anal Gland neoplasms) AND ("Probiotic *" OR "Lactobacillus", "Bacillus coagulans" OR "Propionibacterium" OR "Bifidobacterium" OR "Saccharomyces") AND ("Microbiota" OR "Human Microbiome" OR " Microbial Community" OR " Microbial Community Composition" OR "Microbial "Community Structure" OR "Microbiome" OR "Gastrointestinal Microbiome" OR "Microbial Consortia" OR "Metagenome" OR "Mycobiome" OR "Periphyton" OR "Gut Microbiota" OR "Gut Microbiome") were assessed.

The search was restricted to studies published in the English language and carried only in humans. Exclusion criteria included: conference publications, articles available only in abstract form (no possible contact with authors).

\subsection{Data Extraction}

Identified studies from the electronic databases were screened by title and abstract by two independent reviewers. Full texts were retrieved if decisions could not be made based on the information provided in the abstract. Disagreements regarding selection were resolved by discussion or consensus by all authors. After determination of study selection, the following data were extracted: first author's name, year of publication, study design, sample size, mean age and gender of trial participants, Body Mass Index (BMI), microbiota composition changes, method used for bacterial DNA isolation, probiotic strain, dosage in 
grams and duration of probiotic intervention. Additionally, the stage of colon cancer and its location were collected. Changes in selected biochemical and inflammatory parameters (i.e., hsCRP, IL-2, hemoglobin) were retrieved.

\subsection{Risk of Bias Tool}

In order to assess the methodological quality of the studies included in this review, we used the "Cochrane Handbook of Systematic Reviews of Interventions" [22], evaluating the risk of bias in each of the proposed items: (a) selection bias, (b) performance bias, (c) detection bias, (d) attrition bias and (e) reporting bias.

\section{Results}

\subsection{Study Selection and Characteristics of Study Population}

The detailed steps of the study selection process are given as a flowchart in Figure 1. An initial literature search generated a total of 198 articles. After removing duplicates, the titles and abstracts were screened independently by two reviewers. By evaluating the titles and abstracts and full-text, additional studies were excluded as irrelevant (unrelated topics or irrelevant design). Finally, 6 studies [23-28] with a total of 457 participants were included in the study. All of them were RCTs with a duration ranging up to 78 days [27], published between 2007-2017. The median age of patients was 65.4 years old and they were characterized by the median BMI value: $23.8 \mathrm{~kg} / \mathrm{m}^{2}$. Most of the studies were conducted in the European population [26-28], two trials in Japanese [23,24], and one in Chinese [25]. Only one study mentioned diet, where patients received regular diet preoperatively and a low residue diet one day before the surgery [25]. Colorectal cancer staging was performed in two studies using the Classification of Malignant Tumors (TNM), where T refers to the size and extent of the main tumor, $\mathrm{N}$ to the number of nearby lymph nodes that have malignant changes and $M$ refers to distal metastasis [24,27] and one study using the Astler-Coller classification [25]. Tumor location was assessed in four studies [23-26]. In the majority of patients the tumor was localized in the colon. The following probiotics strains were used: Bifidobacterium longum BB536 [23]; Enterococcus faecalis T110, Clostridium butyricum TO-A Bacillus mesentericus TO-A [24]; Bifidobacterium lactis B1-04 (ATCC SD5219), Lactobacillus acidophilus NCFM (ATCC 70039) [27]; Lactobacillus plantarum (CGMCC No. 1258), Lactobacillus acidophilus LA-11, Bifidobacterium longum BL-88 [25]; Bifidobacterium longum (BB536), Lactobacillus johnsonii (La1) [26]; Oligofructose enriched inulin (SYN1), Lactobacillus rhamnosus GG (LGG), and Bifidobacterium lactis Bb12 (BB12) [28]. Tables 1 and 2 present the detailed characteristics of the selected studies.

\subsection{Effect of Probiotics on Changes in Gut Microbiota and Postoperative Outcome}

Alterations in the enteric microbiota were reported in all studies [23-28]. We summarized the representative taxa at two levels (phylum and genus levels) and the effects of the probiotic intervention on the fecal flora of cancer patients were presented in Table 3 . In five studies, microbiota was evaluated by means of the PCR amplification technique [23-27]. In one study standard plate count techniques were used [27]. The supplementation with a combination of Lactobacillus bacteria, including L. acidophilus, L. plantarum, L. rhamnosus species and Bifidobacterium bacteria [24,26,27], including B. lactis and B. longum species was associated with an increased abundance of positive bacteria such as: Bifidobacterium, Lactobacillus, Bacillus, Eubacterium and Peptostreptococcus. Moreover, the use of this probiotic strain mix reduced the enteropathogenic bacteria: Enterococcus, Fusobacterium, Porphyromonas and Pseudomonas [24-27]. Furthermore, intervention with Enterococcus faecalis, Clostridium butyriucm and Bacillus mesentericus increased the abundance of positive bacteria-Bifidobacterium [23].

Additionally, probiotic strains-Bifidobacterium longum, Bifidobacterium lactis, Lactobacillus rhamnosus and Lactobacillus johnsoni-were associated with positive changes in the biochemical and inflammatory parameters. Bifidobacterium longum supplementation increased serum hemoglobin, erythrocyte, lymphocyte, total protein and albumin concentration, whereas it decreased high sensitive C-reactive proteins (hsCRP) [23]. Furthermore, 
a combination of Bifidobacterium longum and Lactobacillus acidophilus reduced the expression of the dendritic phenotypes CD83-123, CD83-HLADR, and CD83-11c (markers of activation) [26]. Synbiotic administration (Lactobacillus rhamnosus, Bifidobacterium lactis and Oligofructose enriched inulin) increased barrier function and production of interferon- $\gamma$ (IFN- $\gamma$ ) and decreased secretion of interleukin 2 (IL-2) [28].
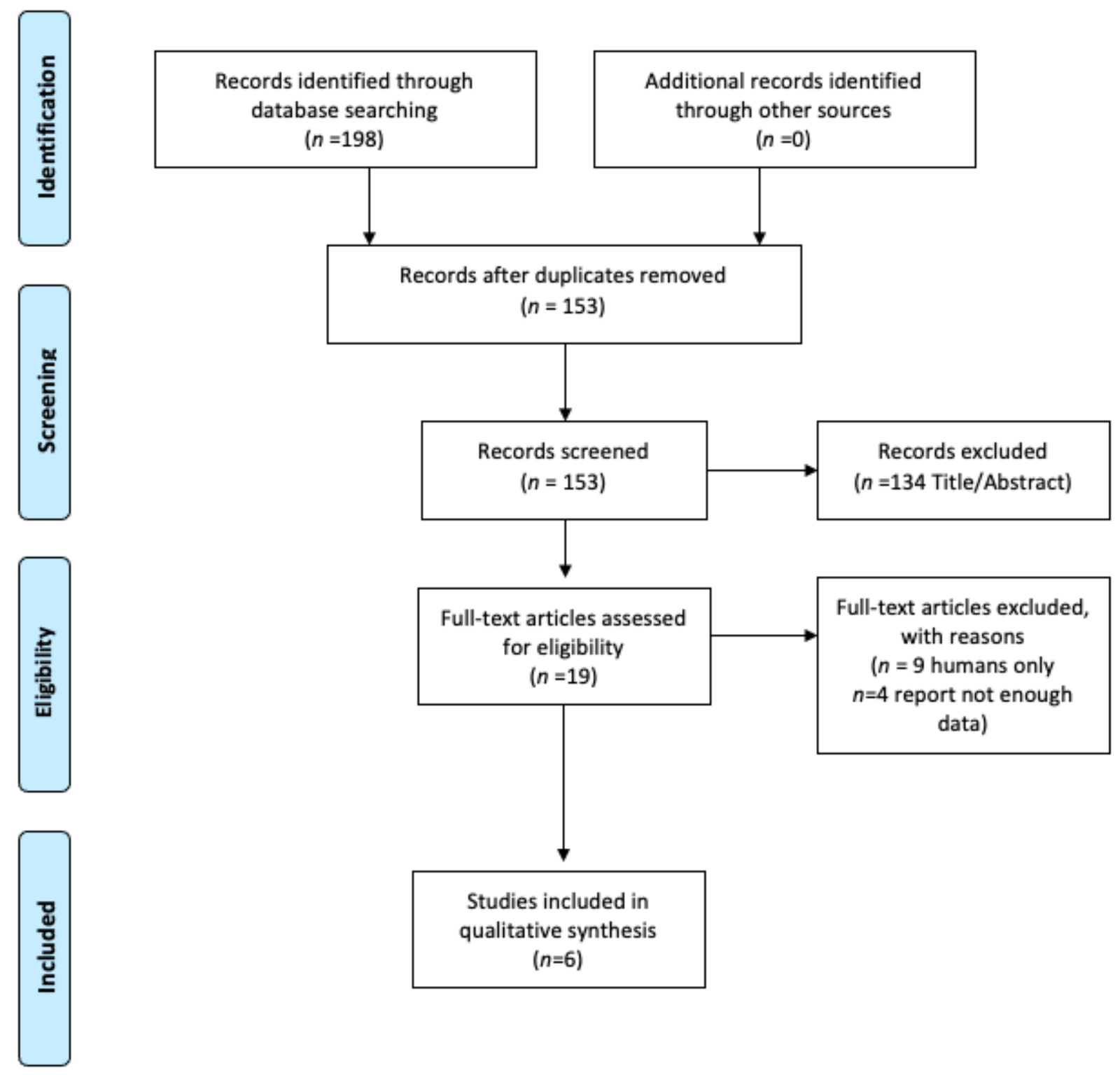

Figure 1. Flow chart of the databases search on influence of probiotics/synbiotics administration on gut microbiota in patients with colorectal cancer (CRC). 
Table 1. Characteristics of enrolled population $(n=457)$.

\begin{tabular}{|c|c|c|c|c|c|c|c|c|c|c|c|c|c|c|c|c|c|c|}
\hline \multirow{2}{*}{$\begin{array}{l}\text { Source, } \\
\text { Year }\end{array}$} & \multirow{2}{*}{$\begin{array}{l}\text { Trial } \\
\text { Type }\end{array}$} & \multicolumn{3}{|c|}{ Sample Size $(n)$} & \multicolumn{3}{|c|}{ Age (years) } & \multicolumn{3}{|c|}{$\operatorname{Sex}(M / F n)$} & \multicolumn{3}{|c|}{ BMI $\left(\mathrm{kg} / \mathrm{cm}^{2}\right)$} & \multicolumn{2}{|c|}{ Stage } & \multicolumn{3}{|c|}{ Location } \\
\hline & & $\begin{array}{l}\text { Control } \\
\text { Group }\end{array}$ & \multicolumn{2}{|c|}{ Probiotic Group } & $\begin{array}{l}\text { Control } \\
\text { Group }\end{array}$ & \multicolumn{2}{|c|}{ Probiotic Group } & $\begin{array}{l}\text { Control } \\
\text { Group }\end{array}$ & $\begin{array}{r}\text { Probi } \\
\text { Gro }\end{array}$ & & $\begin{array}{l}\text { Control } \\
\text { Group }\end{array}$ & \multicolumn{2}{|c|}{ Probiotic Group } & $\begin{array}{l}\text { Control } \\
\text { Group }\end{array}$ & $\begin{array}{l}\text { Probiotic } \\
\text { Group }\end{array}$ & Control Group & \multicolumn{2}{|c|}{ Probiotic Group } \\
\hline $\begin{array}{l}\text { Mizuta } \\
\text { et al., } \\
2016\end{array}$ & PRCL & $n=29$ & \multicolumn{2}{|c|}{$n=31$} & $71.2 \pm 9.5$ & \multicolumn{2}{|c|}{$68.9 \pm 10.4$} & $15 / 14$ & \multicolumn{2}{|c|}{$20 / 11$} & $24.1 \pm 3.4$ & \multicolumn{2}{|c|}{$22.4 \pm 3.7$} & $\mathrm{n} / \mathrm{A}$ & $\mathrm{n} / \mathrm{A}$ & $\begin{array}{l}\text { Colon } 12 \\
\text { Rectum } 13 \\
\text { Others } 4 * * *\end{array}$ & \multicolumn{2}{|c|}{$\begin{array}{l}\text { Colon } 11 \\
\text { Rectum } 19 \\
\text { Others } 0\end{array}$} \\
\hline $\begin{array}{l}\text { Aisu } \\
\text { et al., } \\
2014\end{array}$ & RCT & $n=81$ & \multicolumn{2}{|c|}{$n=75$} & $69.1 \pm 11.3$ & \multicolumn{2}{|c|}{$68.0 \pm 13.8$} & $44 / 37$ & \multicolumn{2}{|c|}{$47 / 28$} & $23.3 \pm 3.8$ & \multicolumn{2}{|c|}{$21.7 \pm 2.7$} & $\begin{array}{l}\text { I } 29 \\
\text { II } 32 \\
\text { IIIA } 11 \\
\text { IIIB } 3 \\
\text { IV } 6 *\end{array}$ & $\begin{array}{l}\text { I } 31 \\
\text { II } 16 \\
\text { IIIA } 10 \\
\text { IIIB } 3 \\
\text { IV } 8^{*}\end{array}$ & $\begin{array}{c}\text { Colon } 3 \\
\text { Ascending colon } 8 \\
\text { Transverse colon } 6 \\
\text { Descending colon } 3 \\
\text { Sigmoid colon } 25 \\
\text { Rectum } 22\end{array}$ & \multicolumn{2}{|c|}{$\begin{array}{c}\text { Colon } 5 \\
\text { Ascending colon } 14 \\
\text { Transverse colon } 5 \\
\text { Descending colon } 0 \\
\text { Sigmoid colon } 16 \\
\text { Rectum } 8\end{array}$} \\
\hline $\begin{array}{l}\text { Hibberd } \\
\text { et al., } \\
2017\end{array}$ & RCT & $n=21$ & \multicolumn{2}{|c|}{$n=15$} & $63(55-73)$ & \multicolumn{2}{|c|}{77 (68-75) } & $4 / 17$ & \multicolumn{2}{|c|}{$6 / 9$} & $\mathrm{n} / \mathrm{A}$ & \multicolumn{2}{|c|}{$24.1(22.5-24.8)$} & $\mathrm{n} / \mathrm{A}$ & $\begin{array}{c}\text { I } 2 \\
\text { II } 6 \\
\text { III } 7 \text { * }\end{array}$ & $\mathrm{n} / \mathrm{A}$ & \multicolumn{2}{|c|}{$\mathrm{n} / \mathrm{A}$} \\
\hline $\begin{array}{l}\text { Liu } \\
\text { et al., } \\
2010\end{array}$ & RDBT & $n=50$ & \multicolumn{2}{|c|}{$n=50$} & $65.7 \pm 9.9$ & \multicolumn{2}{|c|}{$65.3 \pm 11.0$} & $31 / 19$ & \multicolumn{2}{|c|}{$28 / 22$} & $22.6 \pm 2.0$ & \multicolumn{2}{|c|}{$22.8 \pm 1.8$} & $\begin{array}{l}\text { A } 12 \\
\text { B } 29 \\
\text { C } 9 \text { ** }\end{array}$ & $\begin{array}{l}\text { A } 11 \\
\text { B } 30 \\
\text { C } 9 * *\end{array}$ & $\begin{array}{l}\text { Transverse Colon } 8 \\
\text { Descending Colon } 10 \\
\text { Sigmoid colon } 21 \\
\text { Rectum } 11\end{array}$ & \multicolumn{2}{|c|}{$\begin{array}{c}\text { Transverse Colon } 7 \\
\text { Descending Colon } 5 \\
\text { Sigmoid colon } 25 \\
\text { Rectum } 13\end{array}$} \\
\hline & & & $\begin{array}{l}\text { Low } \\
\text { dose }\end{array}$ & $\begin{array}{l}\text { High } \\
\text { dose }\end{array}$ & & Low dose & High dose & & $\begin{array}{l}\text { Low } \\
\text { dose }\end{array}$ & $\begin{array}{l}\text { High } \\
\text { dose }\end{array}$ & & Low dose & High dose & & & Left colon 4 & Low dose & High dose \\
\hline $\begin{array}{l}\text { et al., } \\
2010\end{array}$ & RDBT & $n=10$ & $n=11$ & $n=10$ & $63.3 \pm 10.2$ & $64.7 \pm 4.8$ & $62.7 \pm 7.8$ & $7 / 3$ & $8 / 3$ & $7 / 3$ & $25.6 \pm 2.6$ & $26.5 \pm 4.1$ & $24.4 \pm 3.7$ & $\mathrm{n} / \mathrm{A}$ & $\mathrm{n} / \mathrm{A}$ & $\begin{array}{l}\text { Right colon } 3 \\
\text { Rectum } 3\end{array}$ & $\begin{array}{l}\text { Left colon } 6 \\
\text { Right colon } \\
2 \text { Rectum } 3\end{array}$ & $\begin{array}{l}\text { Left colon } 5 \\
\text { Right colon } \\
2 \text { Rectum } 3\end{array}$ \\
\hline $\begin{array}{l}\text { Rafter } \\
\text { et al., } \\
2007\end{array}$ & RDBPCT & $n=40$ & & & $57.0 \pm 9.75$ & 61.1 & 5.55 & $22 / 18$ & $21 /$ & & $\mathrm{n} / \mathrm{A}$ & & A & $\mathrm{n} / \mathrm{A}$ & $\mathrm{n} / \mathrm{A}$ & $\mathrm{n} / \mathrm{A}$ & & \\
\hline
\end{tabular}

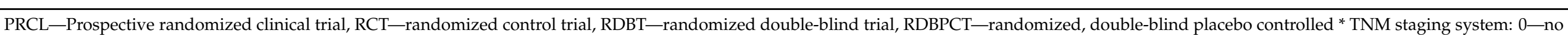

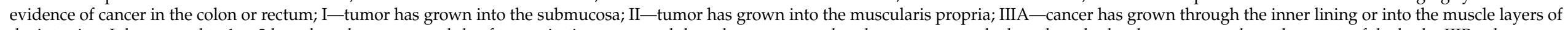

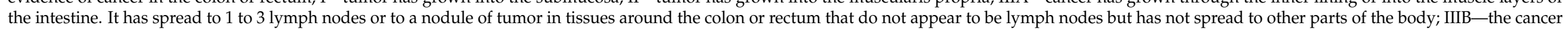

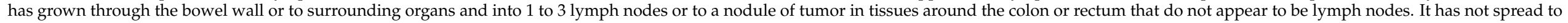

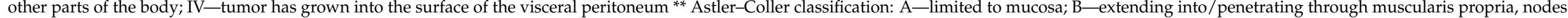
not involved; C-extending into/penetrating through muscularis propria, nodes involved. 
The intervention with bacterial strains of Lactobacillus plantarum, Lactobacillus acidophilus, and Bifidobacterium longum [25] was associated with a lower postoperative incidence of bacterial translocation and increased mean colon mucosal transepithelial resistance. On the contrary, the use of these bacteria was associated with reduced transmucosal permeation of the lactulose/mannitol ratio, horseradish peroxidase and decreased ilealbile acid-binding protein [25]. Furthermore, pre- and postsurgical supplementation with Lactobacillus plantarum, Lactobacillus acidophilus, and Bifidobacterium longum resulted in reduced hospitalization time and improved peristalsis of the intestine [23,25]. In addition, reduced postoperative abdominal distension, abdominal cramping and reduced pyrexia were observed [25]. Bacterial strains of Enterococcus faecalis, Clostridium butyricum and Bacillus mesentericus reduced postoperative and surgical superficial incisional infections and reduced the length of time prior to the passage of gas [24].

Table 2. Probiotic supplementation and CRC: outcomes of clinical studies.

\begin{tabular}{|c|c|c|c|}
\hline Scheme & Probiotic Intervention Dose (g) & Duration (Days) & Key Results \\
\hline Mizuta et al., 2016 & $\begin{array}{c}2 \mathrm{~g} \text { of Bifidobacterium longum } \\
\text { BB536 powder (approximately } \\
\left.5 \times 10^{10} \mathrm{CFU} / 2 \mathrm{~g}\right)\end{array}$ & $21-28$ & $\begin{array}{c}\uparrow \text { anti-inflammatory response }(\downarrow \text { high } \\
\text { sensitive C-reactive proteins, } \\
\uparrow \text { postoperative levels of erythrocytes, } \\
\text { hemoglobin, lymphocytes, total } \\
\text { protein, and albumin) } \\
\downarrow \text { duration of hospital stay }\end{array}$ \\
\hline Aisu et al., 2014 & $\begin{array}{c}2 \mathrm{mg} \text { Enterococcus faecalis T110, } \\
0.01 \mathrm{~g} \text { Clostridium butyricum TO-A } \\
\text { and } 0.01 \mathrm{~g} \text { Bacillus mesentericus } \\
\text { TO-A } 6 \times 10^{9} \mathrm{CFU} / \mathrm{d}\end{array}$ & 15 & $\begin{array}{c}\downarrow \text { incidence of postoperative } \\
\text { complications }(\downarrow \text { time of flatus, } \downarrow \text { time } \\
\text { of meal intake, } \downarrow \text { superficial } \\
\text { incisional infections }\end{array}$ \\
\hline Hibberd et al., 2017 & $\begin{array}{l}1.4 \times 10^{10} \text { CFUs Bifidobacterium } \\
\text { lactis Bl-04 (ATCC SD5219), } \\
7 \times 10^{9} \text { CFUs Lactobacillus } \\
\text { acidophilus NCFM (ATCC 700396) } \\
\text { and } 0.63 \text { g inulin. }\end{array}$ & $8-78$ & $\begin{array}{c}\uparrow \text { anti-inflammatory response } \\
\uparrow \text { microbial diversity: } \alpha \text { - diversity } \\
\text { and } \beta \text {-diversity }\end{array}$ \\
\hline Liu et al., 2010 & $\begin{array}{c}\text { Lactobacillus plantarum }(\mathrm{CGMCC} \\
\text { No. } 1258, \text { cell count } \geq \\
\left.10^{11} \mathrm{CFU} / \mathrm{g}\right), \text { Lactobacillus } \\
\text { acidophilus }(\mathrm{LA}-11, \text { cell count } \geq \\
\left.7.0 \times 10^{10} \mathrm{CFU} / \mathrm{g}\right) \text { and } \\
\text { Bifidobacterium longum }(\mathrm{BL}-88, \\
\left.\text { cell count } \geq 5.0 \times 10^{10} \mathrm{CFU} / \mathrm{g}\right)\end{array}$ & 16 & $\begin{array}{c}\downarrow \text { incidence of postoperative } \\
\text { complications ( } \downarrow \text { abdominal } \\
\text { cramping, } \downarrow \text { abdominal distention, } \\
\downarrow \text { duration of pyrexia } \downarrow \text { time to } \\
\text { first defecation) } \\
\downarrow \text { incidence of diarrhea } \\
\uparrow \text { microbial diversity: } \alpha \text { - diversity } \\
\text { and } \beta \text {-diversity }\end{array}$ \\
\hline Gianotti et al., 2010 & $\begin{array}{l}2 \times 10^{7} \text { CFU/d of a mixture of } \\
\text { Bifidobacterium longum (BB536) } \\
\text { and Lactobacillus johnsonii (La1) }\end{array}$ & 6 & $\begin{array}{c}\uparrow \text { anti-inflammatory response }(\uparrow \mathrm{CD} 3, \\
\text { CD4, CD8, dendritic phenotypes } \\
\text { CD83-123, } \downarrow \text { CD83-HLA DR, } \\
\text { CD83-11c) }\end{array}$ \\
\hline Rafter et al., 2007 & $\begin{array}{l}\text { Oligofructose enriched inulin } \\
\text { (SYN1) and Lactobacillus } \\
\text { rhamnosus GG (LGG) and } \\
\text { Bifidobacterium lactis Bb12 (BB12), } \\
12 \text { g SYN1 together with the } \\
\text { probiotic capsule }>\log _{10} \text { CFU/g }\end{array}$ & 42 & $\begin{array}{c}\uparrow \text { anti-inflammatory response } \\
\text { ( } \uparrow \text { interferon } \gamma, \downarrow \text { interleukin (IL) 2) } \\
\downarrow \text { proliferation rate of colorectal cells }\end{array}$ \\
\hline
\end{tabular}


Table 3. Effect of probiotics on specific bacteria.

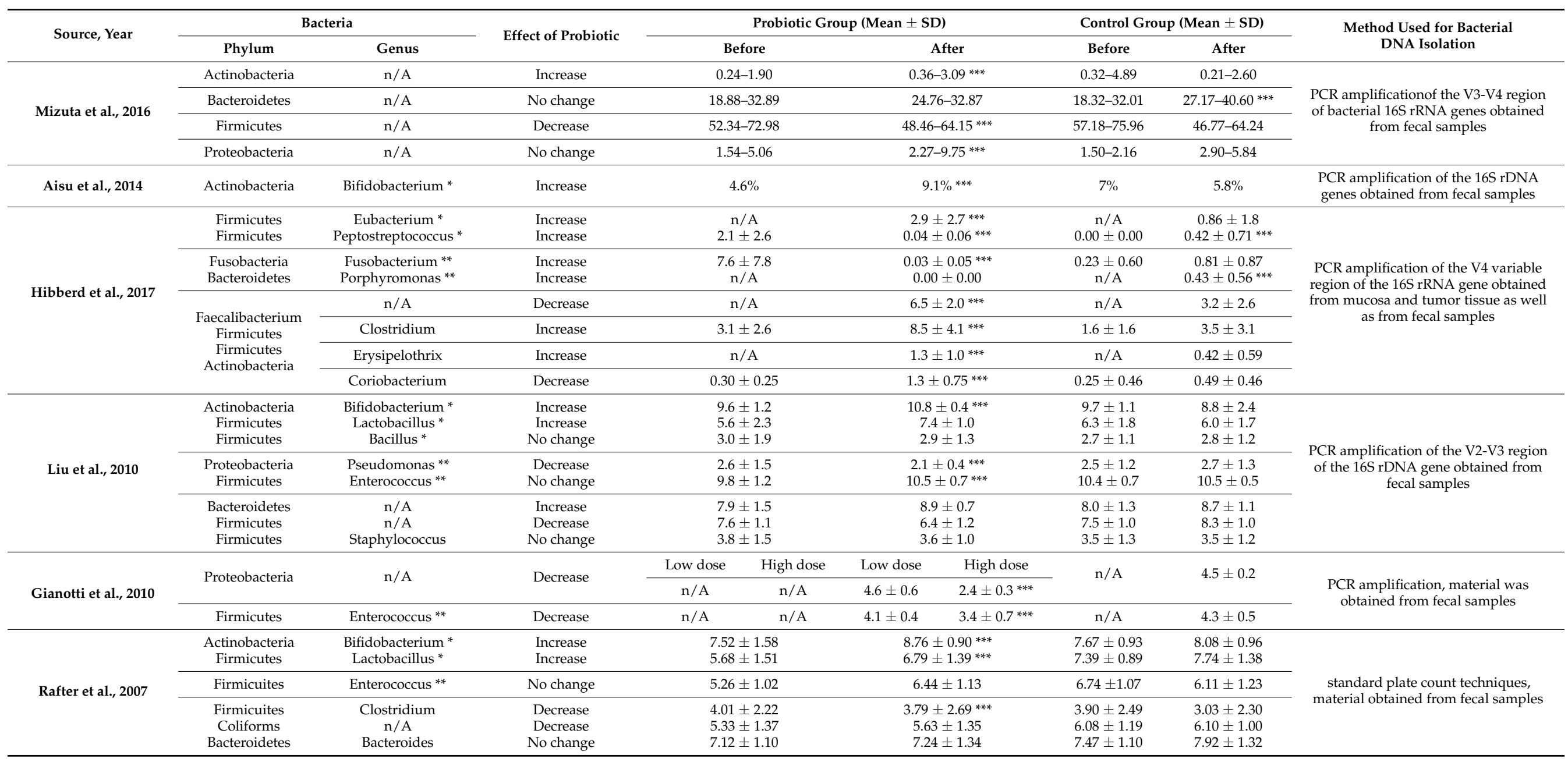

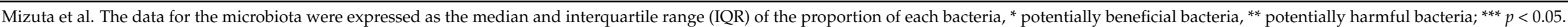




\subsection{Risk of Bias Assessment}

The distribution of biases classified as "low risk" or "unclear risk" was similar, except for detection bias, which presented a $80 \%$ "unclear" risk. Detection bias is related to the blinding of the assessors to the study results, and although the Cochrane manual states that their blinding does not ensure success, a lack of blinding could bias the study results. Nevertheless, the predominant classification of this type of bias, in particular, was "unclear risk" and not "high risk", which is associated with a lack of information regarding this bias on the part of the authors, rather than a possible bias in the results (Figure 2).

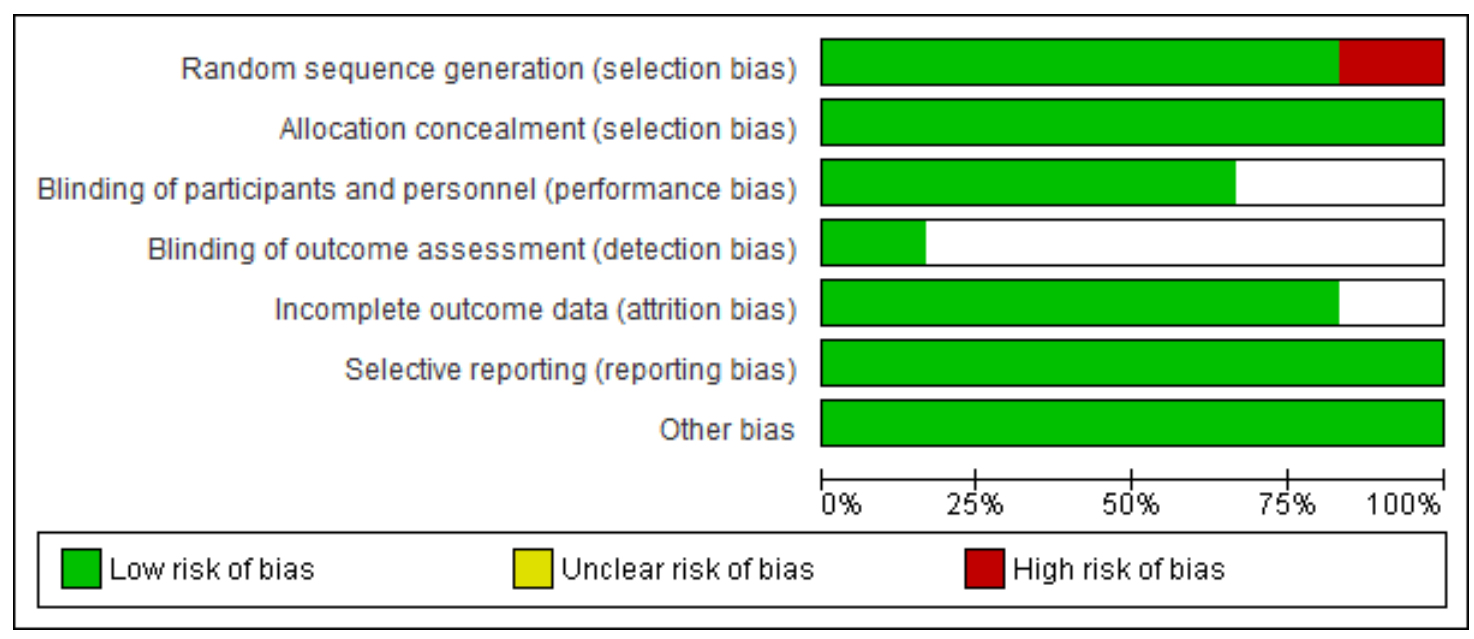

Figure 2. Risk of bias graph: review authors' judgements about each risk of bias item presented as percentages across all included studies.

\section{Discussion}

A number of studies have shown that the consumption of certain probiotics is able to beneficially alter the predisposing factors of CRC, and is a promising approach for management of CRC. Our study confirmed that particular combinations of strains or specific species of pro-/synbiotics have beneficial effects in CRC patients in terms of increasing antimicrobial defense, improving intestinal integrity and immune response. The most commonly investigated probiotic bacteria were Lactobacillus and Bifidobacterium [23,25-28]. The study presented by Hibberd et al. [27] suggested that intervention with probiotic mix of Bifidobacterium lactis Bl-04, Lactobacillus acidophilus NCFM markedly improved the abundance of butyrate-producing bacteria such as Clostridiales and Faecalibacterium species. The main products of the substrate fermentation in the gut are short-chain fatty acids (SCFAs) that interact with the intestinal microbiota and the host cell [29]. Additionally, the SCFA butyrate is responsible for the epithelial function through the induction of genes encoding tight junctions components. Due to their potential therapeutic anti-inflammatory components, some strains of Lactobacilli and Bacillus may positively influence the activity of inflammation [30]. Moreover, Lactobacillus and Bifidobacterium spp. may change the expression of genes involved in cell proliferation, apoptosis, cell death and metastasis [31]. A study conducted by Moore and Moore [32] showed that an increased abundance of Eubacterium aerofaciens and Lactobacillus was protective against the formation of colon polyps. Furthermore, reduced levels of the tumor-inducing microbial agents Fusobacterium and Peptostreptococcus were observed [27]. It has been reported that Fusobacterium spp. may possess virulence characteristics which contribute to the increased adhesiveness to host epithelial cells [33]. Finally, the overexpression of both Fusobacterium and Peptostreptococcus genera may promote proinflammatory environment and cause periodontitis [34]. Interestingly, Pseudomonas enhance the formation of a local anaerobic environment which is viable for colonization by Peptostreptococcus, Fusobacterium and Lactococcus [35]. He et al. [36] investigated the effect of probiotic/synbiotic supplementation in CRC patients and ob- 
served an improvement in enteric microbiota by increasing Lactobacillus and reducing the Enterobacteriaceae members. This stays in line with our study. Huycke et al. [37] showed that Enterococcus faecalis produces DNA damaging superoxide radicals and extracellular genotoxins which may contribute to CRC development. Another worthwhile study investigated the effect of probiotic mix (B. longum, L. acidophilus, and E. faecalis) on CRC patients who have undergo radical colorectomy [38]. A significant reduction in Fusobacterium species and improved diversity of the mucosa-associated microbiota were visible. Finally, this study suggested that probiotic supplementation may improve state of health of CRC by positive regulation and alteration of mucosal-associated microbiota [38]. In animal models the intervention with Lactobacillus salivarius Ren resulted in reduction in Bacteroides dorei, Clostridiales, Ruminococcus species and the level of Prevotella species increased [39].

Multiple studies have shown that by reducing intestinal permeability and increasing microbial diversity, probiotics are able to lower the rates of postoperative complications [17-19,36]. It has commonly been assumed that multiple factors such as enteric barrier disruption, increased intestinal permeability, and host immunologic compromise account for postoperative infectious complications $[33,34]$. One of the mechanisms of action of probiotics is the suppression of pathogens and the manipulation of gut microbiota by inducing the host's secretion of IgA from plasma cells and $\beta$-defensins from intestinal epithelial cells [40]. Lactobacillus rhamnosus GG and Bifidobacterium lactis Bb-12 have been shown to enhance IgA production in the gut mucosa [41]. Furthermore, probiotics will secure the intestinal barrier through the mediation of cytokine secretion, the activation of natural killer cells, and as a result, will contribute to dendritic cell maturation [42]. Lactobacillus gasseri 4M13 and Lactobacillus rhamnosus 4B15 have shown anti-inflammatory properties by inhibiting the expression of inflammatory cytokines at transcriptional level in vitro [43]. In addition, certain probiotics, such as Bifidobacterium longum, Lactobacillus acidophilus ATCC, benefit the host by reducing intestinal inflammation by inhibiting the activation of nuclear factor $\mathrm{K} B$ (NF- KB) [44-46]. Lactobacilli, through the production of bacteriocins, hydrogen peroxide and lactic acid, are able to inhibit intestinal pathogens [47]. Changes in the above pathways might also affect the proliferation and survival of target cells [40].

Recent scientific studies shed light upon the relationship between probiotic use and postoperative outcomes. Postsurgical complications such as diarrhea or pyrexia markedly increase the risk of infections and prolong hospital stay in patients with CRC [48]. It has been shown that supplementation with combination of Lactobacillus and Bifidobacterium bacteria resulted in significantly reduced hospitalization time and improved peristalsis of the intestine $[23,25]$. Furthermore, this systematic literature review (SLR) reported that probiotic administration contributed to reduced postoperative abdominal distension and abdominal cramping. Similarly, Tan et al. [49] studied the influence of preoperative probiotic mixture (Lactobacillus acidophilus, Lactobacillus casei, Lactobacillus lactis, Bifiobacterium infantis, Bifiobacterium bifidum, and Bifiobacterium longum) on patients with CRC. A markedly reduced hospitalization period and time needed for regaining normal enteric function after surgery were observed in the intervention group. Previous studies $[50,51]$ confirmed that the probiotic/synbiotic intervention among antibiotic therapy significantly reduced hospitalization time and septic complications. This is critically important since shorter antibiotic treatment results in a decrease in emerging bacterial resistance. Furthermore, intervention with B. longum, L. acidophilus, and E. faecalis reduced the prevalence of diarrhea and significantly improved the bowel movement in CRC patients [52]. This SLR revealed that perioperative probiotic supplementation of Enterococcus faecalis T110, Clostridium butyricum TO-A, and Bacillus mesentericus TO-A significantly reduced postoperative superficial incisional surgical site infections [24]. In line with these observations, the administration of Lactobacillus casei along with Bifidobacterium breve markedly reduced the incidence of postsurgical infectious complications [53].

Moreover, an anti-inflammatory response was visible within this SLR, as described by the significant reduction in serum hsCRP, IL-2, CD83-123, CD83-HLADR and CD8311c concentrations interlinked with significant increase serum concentrations of IFN- $\gamma$, 
CD3, CD4, CD8, hemoglobin, erythrocytes, lymphocytes, total protein [23,26,28]. Actinobacteria were positively associated with erythrocytes, hemoglobin, albumin, NK cell activity, whereas Firmicutes were positively associated with albumin, total protein, and lymphocytes, but negatively correlated with hCRP, IL-6 and white blood cells [23]. On contrary, supplementation with Lactobacillus plantarum BFE 1685 and Lactobacillus johnsonii BFE 6128 have been proven to help in modulating the immune system by inducing the release of the cytokine IL-8 in vitro [54]. Furthermore, the supplementation of Lactobacillus acidophilus, Lactobacillus lactis, Lactobacillus casei and Bifidobacterium longum, Bifidobacterium bifidum, Bifidobacterium has been proven to significantly reduce the level of proinflammatory cytokines, IL-6, IL-10, IL-12, IL-17A, IL-17C, IL-22 and TNF-alpha in intervention group comparing to placebo [55]. In animal models the effect of Lactobacillus plantarum and Lactobacillus rhamnosus strains was investigated where the supplementation with Lactobacillus plantarum markedly increased the lifespan of tumor-bearing mice and diminished the CT26 cell growth by enhancing the CD8+ function, Th1-type CD4 + T differentiation, IFN- $\gamma$ expression and NK cell infiltration compared to Lactobacillus rhamnosus [56].

There are some limitations to this study. Firstly, all the included studies were published only in English, which might lead to the loss of valuable studies in different languages. Secondly, the retrieved studies were marred by significant heterogeneity including the strain, amount, duration, and schedule of the pro-/symbiotics intervention. Thirdly, there was a lack of uniformity in the accompanying medications and surgical intervention in each of the included studies. Finally, the detection bias was related to the blinding of the assessors to the study results and could have an influence on the study results.

\section{Conclusions}

In conclusion, current review indicated that the use of pro-/synbiotics may have a positive influence on enteric microbiota and gut barrier function, which may be related to the improvement in postoperative outcomes. Furthermore, amongst combination probiotics, and the nine-strain combination of two Bifidobacterium, one Enterococcus, one Bacillus, one Clostridium, four Lactobacillus was associated with improvement in overall symptoms. Moreover, the increased abundance of beneficial bacteria such as Lactobacillus and Bifidobacterium was observed during intervention. Nevertheless, still there is a need to prove probiotic administration in CRC patients before we consider this approach as promising for the treatment of CRC.

Author Contributions: A.W. and D.M.-W.: databases search; A.W. and D.M.-W.: writing-original draft preparation, review and editing; M.M. and M.S.-M.: reviewing, conceptualization and supervision. All authors have read and agreed to the published version of the manuscript.

Funding: This research received no external funding.

Institutional Review Board Statement: The single studies included in this SLR were conducted according to the guidelines of the Declaration of Helsinki, and approved by the single Institutional Review Boards (or Ethics Committees). As the design of this study was systematic literature review it does not require additional review board approval.

Informed Consent Statement: Not applicable.

Data Availability Statement: To get an access to secondary data please contact correspondence author.

Conflicts of Interest: The authors declare no conflict of interest.

\section{References}

1. Siegel, R.L.; Miller, K.D.; Goding Sauer, A.; Fedewa, S.A.; Butterly, L.F.; Anderson, J.C.; Cercek, A.; Smith, R.A.; Jemal, A. Colorectal Cancer Statistics, 2020. CA Cancer J. Clin. 2020, 70, 145-164. [CrossRef]

2. Sinicrope, F.A. DNA Mismatch Repair and Adjuvant Chemotherapy in Sporadic Colon Cancer. Nat. Rev. Clin. Oncol. 2010, 7, 174-177. [CrossRef] 
3. Schell, M.J.; Yang, M.; Teer, J.K.; Lo, F.Y.; Madan, A.; Coppola, D.; Monteiro, A.N.A.; Nebozhyn, M.V.; Yue, B.; Loboda, A.; et al. A Multigene Mutation Classification of 468 Colorectal Cancers Reveals a Prognostic Role for APC. Nat. Commun. 2016, 7, 11743. [CrossRef] [PubMed]

4. Clinton, S.K.; Giovannucci, E.L.; Hursting, S.D. The World Cancer Research Fund/American Institute for Cancer Research Third Expert Report on Diet, Nutrition, Physical Activity, and Cancer: Impact and Future Directions. J. Nutr. 2020, 150, 663-671. [CrossRef] [PubMed]

5. Thun, M.; Linet, M.S.; Cerhan, J.R.; Haiman, C.A.; Schottenfeld, D. (Eds.) Cancer Epidemiology and Prevention; Oxford University Press: New York, NY, USA, 2017; Volume 1, ISBN 978-0-19-023866-7.

6. Song, M.; Garrett, W.S.; Chan, A.T. Nutrients, Foods, and Colorectal Cancer Prevention. Gastroenterology 2015, 148, 1244-1260.e16. [CrossRef]

7. Sears, C.L.; Garrett, W.S. Microbes, Microbiota, and Colon Cancer. Cell Host Microbe 2014, 15, 317-328. [CrossRef] [PubMed]

8. Tjalsma, H.; Boleij, A.; Marchesi, J.R.; Dutilh, B.E. A Bacterial Driver-Passenger Model for Colorectal Cancer: Beyond the Usual Suspects. Nat. Rev. Microbiol. 2012, 10, 575-582. [CrossRef] [PubMed]

9. Gagliardi, A.; Totino, V.; Cacciotti, F.; Iebba, V.; Neroni, B.; Bonfiglio, G.; Trancassini, M.; Passariello, C.; Pantanella, F.; Schippa, S. Rebuilding the Gut Microbiota Ecosystem. Int. J. Environ. Res. Public Health 2018, 15, 1679. [CrossRef]

10. Markowiak, P.; Śliżewska, K. Effects of Probiotics, Prebiotics, and Synbiotics on Human Health. Nutrients 2017, 9, 1021. [CrossRef]

11. Interactions between the Microbiota and Pathogenic Bacteria in the Gut. Available online: https://pubmed.ncbi.nlm.nih.gov/27 383983/ (accessed on 9 August 2020).

12. Gensollen, T.; Iyer, S.S.; Kasper, D.L.; Blumberg, R.S. How Colonization by Microbiota in Early Life Shapes the Immune System. Science 2016, 352, 539-544. [CrossRef] [PubMed]

13. Natividad, J.M.M.; Verdu, E.F. Modulation of Intestinal Barrier by Intestinal Microbiota: Pathological and Therapeutic Implications. Pharmacol. Res. 2013, 69, 42-51. [CrossRef] [PubMed]

14. Mego, M.; Chovanec, J.; Vochyanova-Andrezalova, I.; Konkolovsky, P.; Mikulova, M.; Reckova, M.; Miskovska, V.; Bystricky, B.; Beniak, J.; Medvecova, L.; et al. Prevention of Irinotecan Induced Diarrhea by Probiotics: A Randomized Double Blind, Placebo Controlled Pilot Study. Complement. Ther. Med. 2015, 23, 356-362. [CrossRef]

15. Delia, P. Use of Probiotics for Prevention of Radiation-Induced Diarrhea. World J. Gastroenterol. 2007, 13, 912. [CrossRef]

16. Pandey, K.R.; Naik, S.R.; Vakil, B.V. Probiotics, Prebiotics and Synbiotics-A Review. J. Food Sci. Technol. 2015, 52, 7577-7587. [CrossRef] [PubMed]

17. Gibson, G.R.; Hutkins, R.; Sanders, M.E.; Prescott, S.L.; Reimer, R.A.; Salminen, S.J.; Scott, K.; Stanton, C.; Swanson, K.S.; Cani, P.D.; et al. Expert Consensus Document: The International Scientific Association for Probiotics and Prebiotics (ISAPP) Consensus Statement on the Definition and Scope of Prebiotics. Nat. Rev. Gastroenterol. Hepatol. 2017, 14, 491-502. [CrossRef] [PubMed]

18. Sekirov, I.; Russell, S.L.; Antunes, L.C.M.; Finlay, B.B. Gut Microbiota in Health and Disease. Physiol. Rev. 2010, 90, 859-904. [CrossRef]

19. Liberati, A.; Altman, D.G.; Tetzlaff, J.; Mulrow, C.; Gøtzsche, P.C.; Ioannidis, J.P.A.; Clarke, M.; Devereaux, P.J.; Kleijnen, J.; Moher, D. The PRISMA Statement for Reporting Systematic Reviews and Meta-Analyses of Studies That Evaluate Healthcare Interventions: Explanation and Elaboration. BMJ 2009, 339. [CrossRef]

20. Probiotics in Food: Health and Nutritional Properties and Guidelines for Evaluation. Available online: https://www.ncbi.nlm. nih.gov /nlmcatalog/101617803 (accessed on 1 September 2020).

21. Andersson, H.; Asp, N.-G.; Bruce, Å.; Roos, S.; Wadström, T.; Wold, A.E. Health Effects of Probiotics and Prebiotics A Literature Review on Human Studies. Näringsforskning 2001, 45, 58-75. [CrossRef]

22. Shuster, J.J. Review: Cochrane Handbook for Systematic Reviews for Interventions, Version 5.1.0, Published 3/2011. Julian P.T. Higgins and Sally Green, Editors. Res. Synth. Methods 2011, 2, 126-130. [CrossRef]

23. Mizuta, M.; Endo, I.; Yamamoto, S.; Inokawa, H.; Kubo, M.; Udaka, T.; Sogabe, O.; Maeda, H.; Shirakawa, K.; Okazaki, E.; et al. Perioperative Supplementation with Bifidobacteria Improves Postoperative Nutritional Recovery, Inflammatory Response, and Fecal Microbiota in Patients Undergoing Colorectal Surgery: A Prospective, Randomized Clinical Trial. Biosci. Microbiota Food Health 2016, 35, 77-87. [CrossRef]

24. Aisu, N.; Tanimura, S.; Yamashita, Y.; Yamashita, K.; Maki, K.; Yoshida, Y.; Sasaki, T.; Takeno, S.; Hoshino, S. Impact of Perioperative Probiotic Treatment for Surgical Site Infections in Patients with Colorectal Cancer. Exp. Ther. Med. $2015,10,966-972$. [CrossRef]

25. Liu, Z.; Qin, H.; Yang, Z.; Xia, Y.; Liu, W.; Yang, J.; Jiang, Y.; Zhang, H.; Yang, Z.; Wang, Y.; et al. Randomised Clinical Trial: The Effects of Perioperative Probiotic Treatment on Barrier Function and Post-Operative Infectious Complications in Colorectal Cancer Surgery-A Double-Blind Study: Randomised Clinical Trial: Perioperative Probiotics on Colon Cancer. Aliment. Pharmacol. Ther. 2011, 33, 50-63. [CrossRef] [PubMed]

26. Gianotti, L. A Randomized Double-Blind Trial on Perioperative Administration of Probiotics in Colorectal Cancer Patients. World J. Gastroenterol. 2010, 16, 167. [CrossRef]

27. Hibberd, A.A.; Lyra, A.; Ouwehand, A.C.; Rolny, P.; Lindegren, H.; Cedgård, L.; Wettergren, Y. Intestinal Microbiota Is Altered in Patients with Colon Cancer and Modified by Probiotic Intervention. BMJ Open Gastroenterol. 2017, 4, e000145. [CrossRef] [PubMed] 
28. Rafter, J.; Bennett, M.; Caderni, G.; Clune, Y.; Hughes, R.; Karlsson, P.C.; Klinder, A.; O'Riordan, M.; O'Sullivan, G.C.; Pool-Zobel, B.; et al. Dietary Synbiotics Reduce Cancer Risk Factors in Polypectomized and Colon Cancer Patients. Am. J. Clin. Nutr. 2007, 85, 488-496. [CrossRef] [PubMed]

29. Tojo, R. Intestinal Microbiota in Health and Disease: Role of Bifidobacteria in Gut Homeostasis. World J. Gastroenterol. 2014, 20, 15163. [CrossRef] [PubMed]

30. Mańkowska-Wierzbicka, D.; Stelmach-Mardas, M.; Gabryel, M.; Tomczak, H.; Skrzypczak-Zielińska, M.; Zakerska-Banaszak, O.; Sowińska, A.; Mahadea, D.; Baturo, A.; Wolko, Ł.; et al. The Effectiveness of Multi-Session FMT Treatment in Active Ulcerative Colitis Patients: A Pilot Study. Biomedicines 2020, 8, 268. [CrossRef]

31. Nowak, A.; Paliwoda, A.; Błasiak, J. Anti-Proliferative, pro-Apoptotic and Anti-Oxidative Activity of Lactobacillus and Bifidobacterium Strains: A Review of Mechanisms and Therapeutic Perspectives. Crit. Rev. Food Sci. Nutr. 2019, 59, $3456-3467$. [CrossRef]

32. Moore, W.E.; Moore, L.H. Intestinal Floras of Populations That Have a High Risk of Colon Cancer. Appl. Environ. Microbiol. 1995, 61, 3202-3207. [CrossRef]

33. Bachrach, G.; Ianculovici, C.; Naor, R.; Weiss, E.I. Fluorescence Based Measurements of Fusobacterium Nucleatum Coaggregation and of Fusobacterial Attachment to Mammalian Cells. FEMS Microbiol. Lett. 2005, 248, 235-240. [CrossRef]

34. Flynn, K.J.; Baxter, N.T.; Schloss, P.D. Metabolic and Community Synergy of Oral Bacteria in Colorectal Cancer. Msphere 2016, 1, e00102-16. [CrossRef] [PubMed]

35. Gao, Z.; Guo, B.; Gao, R.; Zhu, Q.; Qin, H. Microbiota Disbiosis Is Associated with Colorectal Cancer. Front. Microbiol. 2015, 6. [CrossRef]

36. He, D.; Wang, H.-Y.; Feng, J.-Y.; Zhang, M.-M.; Zhou, Y.; Wu, X.-T. Use of Pro-/Synbiotics as Prophylaxis in Patients Undergoing Colorectal Resection for Cancer: A Meta-Analysis of Randomized Controlled Trials. Clin. Res. Hepatol. Gastroenterol. 2013, 37, 406-415. [CrossRef] [PubMed]

37. Huycke, M.M.; Abrams, V.; Moore, D.R. Enterococcus Faecalis Produces Extracellular Superoxide and Hydrogen Peroxide That Damages Colonic Epithelial Cell DNA. Carcinogenesis 2002, 23, 529-536. [CrossRef] [PubMed]

38. Gao, Z.; Guo, B.; Gao, R.; Zhu, Q.; Wu, W.; Qin, H. Probiotics Modify Human Intestinal Mucosa-Associated Microbiota in Patients with Colorectal Cancer. Mol. Med. Rep. 2015, 12, 6119-6127. [CrossRef]

39. Zhang, M.; Fan, X.; Fang, B.; Zhu, C.; Zhu, J.; Ren, F. Effects of Lactobacillus Salivarius Ren on Cancer Prevention and Intestinal Microbiota in 1, 2-Dimethylhydrazine-Induced Rat Model. J. Microbiol. 2015, 53, 398-405. [CrossRef] [PubMed]

40. Thomas, C.M.; Versalovic, J. Probiotics-Host Communication: Modulation of Signaling Pathways in the Intestine. Gut Microbes 2010, 1, 148-163. [CrossRef] [PubMed]

41. Rautava, S.; Arvilommi, H.; Isolauri, E. Specific Probiotics in Enhancing Maturation of IgA Responses in Formula-Fed Infants. Pediatr. Res. 2006, 60, 221-224. [CrossRef]

42. Takeda, K.; Suzuki, T.; Shimada, S.-I.; Shida, K.; Nanno, M.; Okumura, K. Interleukin-12 Is Involved in the Enhancement of Human Natural Killer Cell Activity by Lactobacillus Casei Shirota. Clin. Exp. Immunol. 2006, 146, 109-115. [CrossRef]

43. Oh, N.S.; Joung, J.Y.; Lee, J.Y.; Kim, Y. Probiotic and Anti-Inflammatory Potential of Lactobacillus Rhamnosus 4B15 and Lactobacillus Gasseri 4M13 Isolated from Infant Feces. PLoS ONE 2018, 13, e0192021. [CrossRef]

44. Tien, M.-T.; Girardin, S.E.; Regnault, B.; Le Bourhis, L.; Dillies, M.-A.; Coppée, J.-Y.; Bourdet-Sicard, R.; Sansonetti, P.J.; Pédron, T. Anti-Inflammatory Effect of Lactobacillus Casei on Shigella-Infected Human Intestinal Epithelial Cells. J. Immunol. 2006, 176, 1228-1237. [CrossRef] [PubMed]

45. Bai, A.-P.; Ouyang, Q.; Xiao, X.-R.; Li, S.-F. Probiotics Modulate Inflammatory Cytokine Secretion from Inflamed Mucosa in Active Ulcerative Colitis: PROBIOTICS MODULATE INFLAMMATORY CYTOKINE SECRETION. Int. J. Clin. Pract. 2006, 60, 284-288. [CrossRef]

46. Resta-Lenert, S.; Barrett, K.E. Probiotics and Commensals Reverse TNF- $\alpha$ - and IFN- $\gamma$-Induced Dysfunction in Human Intestinal Epithelial Cells. Gastroenterology 2006, 130, 731-746. [CrossRef] [PubMed]

47. Reid, G. The Scientific Basis for Probiotic Strains OfLactobacillus. Appl. Environ. Microbiol. 1999, 65, 3763-3766. [CrossRef]

48. Johnson, D.A.; Barkun, A.N.; Cohen, L.B.; Dominitz, J.A.; Kaltenbach, T.; Martel, M.; Robertson, D.J.; Boland, C.R.; Giardello, F.M.; Lieberman, D.A.; et al. Optimizing Adequacy of Bowel Cleansing for Colonoscopy: Recommendations From the US Multi-Society Task Force on Colorectal Cancer. Gastroenterology 2014, 147, 903-924. [CrossRef] [PubMed]

49. Tan, C.K.; Said, S.; Rajandram, R.; Wang, Z.; Roslani, A.C.; Chin, K.F. Pre-Surgical Administration of Microbial Cell Preparation in Colorectal Cancer Patients: A Randomized Controlled Trial. World J. Surg. 2016, 40, 1985-1992. [CrossRef] [PubMed]

50. Pitsouni, E.; Alexiou, V.; Saridakis, V.; Peppas, G.; Falagas, M.E. Does the Use of Probiotics/Synbiotics Prevent Postoperative Infections in Patients Undergoing Abdominal Surgery? A Meta-Analysis of Randomized Controlled Trials. Eur. J. Clin. Pharmacol. 2009, 65, 561-570. [CrossRef]

51. Zhang, J.-W.; Du, P.; Yang, B.-R.; Gao, J.; Fang, W.-J.; Ying, C.-M. Preoperative Probiotics Decrease Postoperative Infectious Complications of Colorectal Cancer. Am. J. Med. Sci. 2012, 343, 199-205. [CrossRef]

52. Yang, Y.; Xia, Y.; Chen, H.; Hong, L.; Feng, J.; Yang, J.; Yang, Z.; Shi, C.; Wu, W.; Gao, R.; et al. The Effect of Perioperative Probiotics Treatment for Colorectal Cancer: Short-Term Outcomes of a Randomized Controlled Trial. Oncotarget 2016, 7, 8432-8440. [CrossRef] 
53. Okazaki, M.; Matsukuma, S.; Suto, R.; Miyazaki, K.; Hidaka, M.; Matsuo, M.; Noshima, S.; Zempo, N.; Asahara, T.; Nomoto, K. Perioperative Synbiotic Therapy in Elderly Patients Undergoing Gastroenterological Surgery: A Prospective, Randomized Control Trial. Nutrition 2013, 29, 1224-1230. [CrossRef]

54. Vizoso Pinto, M.G.; Schuster, T.; Briviba, K.; Watzl, B.; Holzapfel, W.H.; Franz, C.M.A.P. Adhesive and Chemokine Stimulatory Properties of Potentially Probiotic Lactobacillus Strains. J. Food Prot. 2007, 70, 125-134. [CrossRef] [PubMed]

55. Zaharuddin, L.; Mokhtar, N.M.; Muhammad Nawawi, K.N.; Raja Ali, R.A. A Randomized Double-Blind Placebo-Controlled Trial of Probiotics in Post-Surgical Colorectal Cancer. BMC Gastroenterol. 2019, 19, 131. [CrossRef] [PubMed]

56. Hu, J.; Wang, C.; Ye, L.; Yang, W.; Huang, H.; Meng, F.; Shi, S.; Ding, Z. Anti-Tumour Immune Effect of Oral Administration of Lactobacillus Plantarum to CT26 Tumour-Bearing Mice. J. Biosci. 2015, 40, 269-279. [CrossRef] [PubMed] 